\title{
World Cinema, vop Platforms and the Western Demand
}

\author{
Constantin Parvulescu \\ Department of Cinema and Media, Babeș-Bolyai University, Cluj, Romania \\ ctparvulescu@gmail.com
}

\begin{abstract}
The article explores the concept of world cinema as an other to global cinema from a marketing perspective. Special attention is given to the way the world cinema universe is presented on video-on-demand platforms in Western markets. To demonstrate that the stories, scope and concerns of this universe vary according to marketing objectives, the article compares presentations on three platforms with contrasting business models and marketing algorithms: Netflix, Filmin, and FilmDoo. This leads to an important conclustion: presentations on platforms with an apparently more ethical business model are not necessarily more progressive and more advantageous to world cinema in terms of avoiding its "genre-fication".
\end{abstract}

\section{Keywords}

world cinema - voD platforms - global cinema - labelling - marketing

I think of world cinema in opposition to global cinema- that is, to Hollywood and the few other 'Woods' emulating it. This perspective is perhaps Eurocentric, as it can be shown that it is influenced by the way film culture has defined European cinema in opposition to Hollywood. The label 'European' was set to generate an otherness to a threatening production and distribution behemoth associated with the myth of the free global market. 'European' was and still is expected to defend not only the 'competitiveness' of a group of smaller industries, but also less tangible aspects such as cultural diversity and national identity— to use just the most circulated buzzwords. 
According to this model, 'world cinema' gestures toward a cultural and economic protectionist strategy that serves the opening, stimulation and fortification of a market. This means it is indicative of: (1) a demand, (2) a place to sell film experience and engage in other transactions related to it (for example buying distribution rights), (3) specific modes and relations of production (perhaps more sustainable and more egalitarian), and (4) a branding of artisans-directors, actors, production companies, as well as countries of origin, regions of the world, and genres and subgenres.

A quick look at these components reinforces that world cinema is also topologically a Western concept. The demand is Western (Euroamerican and a few other nations with developed economies), the branding is made to serve this demand and so is the actual marketplace. The West has both the interest and the purchasing power to generate tickets sales-for example, at an arthouse theatre in Stockholm or at a festival in Toronto. It is also in the Western regions of the world that other outlets are in place: DVD stores (both at shopping malls and online), public libraries, television, and voD platforms. And most profits from these sales also remain in the West.

Regarding demand, the main consumer of world cinema is also either physically or culturally-based in the global first world. He or she represents the world-film consuming middle class, and usually nurtures liberal political affinities. This statement is valid even when, for example, a world cinema showcase takes place in cities such as Jeddah (Saudi Arabia, Red Sea Film Festival) or Santiago de Chile (SAN FIC). In both these cities, like in a coffee shop in Karlovy Vary during the film festival, one can notice similar behavioural patterns and brands of clothes, and can overhear a conversation between a middle-aged and middle-class couple debating choices of screening. Should they rush to the Irish movie because it has beautiful forest landscapes; to the Palestinian because it's about life on the tormented Gaza Strip, or to the latest Kusturica (pronounced perhaps 'Kusturika') because he's a must-see auteur.

To both stimulate and cater to this demand for foreign film, there are also special funds in Western countries and the EU that support co-production with the world's filmmaking talent. Co-production is a blessing for this talent because it enables access to Western markets and international distribution. The recently made and acclaimed Difret (Zeresenay Berhane Meharim, 2014), for example, is set in Ethiopia and spoken in Amharic. It is presented as an Ethiopian-American venture, which due to having an American partner was selected at the Sundance, Berlin and San Sebastian festivals. It won awards, had a short theatrical release in the US, and benefited from a host reviews and inclusion on 'must-see' lists. It was also shown at several event screenings in 
North America, and then released on the DVD and voD international (Western) markets.

Revealing for the effect on the market of this demand (coupled with the system of EU diversity subsidies mentioned above) is the production of mock world film. One example is another recent project with accolades and international vop distribution titled The Blessed (Les bienheureux, Sofia Djama, 2017). It is set in Algeria, spoken in both French and Arabic, and marketed and reviewed as a film set in Africa (for example by the Federation of African Film Criticism). The world aspect of the film is further enhanced by the fact that it was the director, Sofia Djama, who stood in the awards spotlight. Since she was Algerian-born and based, the world element was even more foregrounded. Yet from an economic perspective, The Blessed is a French property sold on the French-Western market with the original title Les bienheureux.

There are of course various degrees of 'mock' in today's context of filmmaking. They are worth mentioning because the narratives, emotions, characters, and visual spectacle they deliver affect the very diversity that one expects from world. Obviously, worth considering are only projects whose representation does not stridently cross ethical orientalist lines. The Blessed is less of an Ersatz than, for example, The White Knights (Les chevaliers blancs, Joachim Lafosse, Belgium, 2015). The latter feature's merits notwithstanding, it is even less the product of a world imagination. Though set in Africa, delivering African visuals and dealing with topics that one can call 'Africa-related', it is starred, filmed and directed by Europeans. It is a product designed to respond to the demand on the Western and festival market for films that deliver experiences of world-awareness, global humanitarianism and trans-continental solidarity.

I will not talk here about the shelves of public or university libraries that bear the label 'world cinema', or about public television scheduling of world film, all mediating the consumption of this brand of cinema and reinforcing it. I also don't have space to address the work of festival programmers and especially of international distributors even though their selection criteria are important in understanding what world is or, better put, what remains of it. Inclusion in the portfolio of an international distributor can make the difference whether a film crosses borders and becomes 'of the world' or just ends up remaining 'in the world' and providing entertainment on the national market - if the specific producing country has one.

For the rest of my intervention, I will take a closer look at the construction of world on voD platforms (video on demand) because they are seen as representing the future of diversified film consumption and as more effectively able to deliver segmented marketing. I will focus on two mainstream platforms, 
Netflix and Filmin, both subscription vods (svod). However, I will compare their menus with that of one of the very few truly dedicated portals serving world cinema, a pay-per-movie or transactional voD (TVOD). I refer here to FilmDoo, which features a stated imperative 'to get [viewers] connected to the world through film.' It boasts a catalogue of titles from 125 countries and offers homepage menus in non-Western languages, such as Thai and Indonesian.

Before continuing with this analysis, I should note that the contrast between global and world is more obvious when comparing Netflix to FilmDoo. Even if on the commercial side, Filmin stands somewhere in between. One should add that global vs. world is also the effect of the contrast between SVOD and TVOD exploitation - with Filmin being again in the middle, as it includes some TVOD features. However, I don't have the space here to analyse this aspect. I can only mention that TVODs tend to be more related to earlier-day film marketing and exhibition formats including the format of film archives. This is perhaps why, when comparing Netflix and FilmDoo, one is tempted to believe that the organization of FilmDoo and the categories it employs for organizing a world cinema catalogue are somehow the standard in terms of fair trade.

In my opinion it is not necessarily so. Old standards might represent nothing more than another business model that capitalizes on nostalgia and middle class vanity. It is more niche, but not necessarily significantly more helpful per se for the adaptation of the concept of world cinema to contemporary production and marketing standards. However, analysis of world on mainstream platforms like Filmin and Netflix is important because of the turnover of these outlets. Given this situation, their making of world, even can be more impacting than the traditional and more apparently ethical one proposed by FilmDoo.

I argue that higher-traffic platforms such as Netflix and Filmin construct the world film concept differently because they have to embed it in two specific marketing formats. The first embedding is related to their specific subscription services, which is a lump monthly sum that allows access to the entire library. It stands in contrast to the way films are purchased on a TVOD like FilmDoo and other cinephile sites which, like theatres or stores, charge for the rent or purchase of an experiential product at a time. The second embedding specific of these more visible platforms is related to a specific transnational labelling format that they employ, and which is adapted to their global marketing model.

Let us discuss in more detail the first embedding contrast. The overall publicity for these portals foregrounds commercial features that would rather be labelled as global cinema, as well as a host of series mostly Anglo-American. Films that in terms of country of origin, style and language would qualify as world would not be displayed on the home and main screens of these portals. Even if they are included in the libraries of these sites (sometimes because of 
imposed quotas), they would be displayed only on secondary screens generated by a certain browse or search action on behalf of the user. This first and second screen dialectic is an important criterion in the making of world film on these sites.

Like arthouse or other exploitation categories, world becomes the B-feature of a broad double bill offer on platforms like Netflix. World film is the side-product in an updated marketing strategy harking back to the Hollywood studio era. While the main product is global cinema, world is given a hybrid status between being the complimentary 'on the house' service and the proof of the personalization power of online watching. In the case of Netflix, world is that which the lover of cinema or diversity can discover after scrolling or browsing through and away from the attention-grabbing and turning-into-trailer thumbnails of the main offer. It could also emerge as recommended to you (because you watched something similar) but again at the end of a queue that prioritizes the global and featured categories such as 'popular' and the 'trending'.

This layout stands in contrast to the one proposed by FilmDoo. Drawing rather on cinephile procedures that define the A-film according to quality variables such as festival selections and director's ranking (to which, in its early days, Netflix was also more faithful), FilmDoo offers what apparently seems to be a more democratic and less manipulative homepage. There is no stridently imposed hierarchy between the A and B film, and the portal presents the original poster thumbnails and emphasises ethnic, social and stylistic diversity in filmmaking. It makes browsing and searching for this diversity easy, and some diversity is even available for free. It also includes editors' picks, but very low on the page, which, rather than being manipulative, suggests that artistic quality is a criterion in building the platform's library.

Let us discuss in more detail the second embedding and the contrast it generates: labelling and browsing categories. In the case of Filmin and Netflix, browsing categories are genre categories with some variance given to the fact that Filmin is following both commercial objectives and those of servicing Euro-Hispanic cinephiles. Preference for these categories reinforces the B-status of world. That being said, Netflix UK has a 'world cinema' tag. However, the tag is imprecise and leaning towards being a synonym to foreign - that is non-English-speaking or mock foreign - that is coproduced with a non-English speaking country with a 'foreign' topic, but global in everything else, including style and even language (English).

Among Netflix UK's world cinema highest ranked offerings are plenty of such foreign and mock foreign films: The Pianist (Roman Polanski, France, 2002) and The Good, the Bad and the Ugly (Sergio Leone, Italy, 1966), both indeed produced by non-American companies, but starring American talent. Otherwise, 
Bollywood and Spanish-language films occupy most of the screen when ordered by latest additions, with a few European or Asian titles in between. Predictably for UK viewers, Bollywood dominates the top-40 matches even when the screen is ordered according to highest ranking. Bollywood hegemony of the world category allows just one slot for what one could regard as a film with a broader range of world cinema attributes--City of God (Cidade de Deus, Fernando Meirelles and Kátia Lund, Brazil, 2002).

Filmin does not have a 'world cinema' label, but only the expected genre browsing categories. This absence might be an insightful indication of global cinema's Anglocentrism - that is, world cinema is only non-Anglo-American and not non-Hispanic, though the Hispanic market is quite sizeable. Filmin has however country of origin labels such as Venezuela, Hungary and Afghanistan. It has also regional ones, such as 'films set in Africa' or 'oriental cinema'. But both can be accessed only through the search engine (not by browsing). In addition, the platform offers a second set of labels called 'themes'. They function like keywords and can turn intro browsing categories. This can be done, however, only from the page dedicated to a specific film. As such, these themes serve as a basis for further viewing or as a means to generate recommendations.

A combination of these labels and the B-screen status can give a picture as to what world means in a more commercial setting. This status is at variance with that offered by the traditional compartmentalization proposed on FilmDoo. On FilmDoo, directly from the main page, one can select films according to languages spoken and the countries or regions in which they are made (as it was earlier the case on Netflix). ${ }^{1}$ The genre browsing categories on FilmDoo are also at variance with the ones on Netflix and Filmin, though sharing more categories with the latter. They do not coincide with the established commercial genres (drama, comedy, fantasy, etc.), but are rather reminiscent of academic research interests. Browsing categories include: arthouse, black cinema, film debut, female directors, gay and lesbian, road movies, and US independent.

An example is perhaps necessary. Returning to Filmin, and its hybrid characterisation of world, a search for Afghani films that I conducted in September 2019 delivers two titles: The Patience Stone (Syngué sabour/Pierre de Patience, Atiq Rahimi, 2012) and Osama (Siddiq Barmak, 2003). Let us analyse their labelling in order to understand how world is constructed by means of cross-labelling. These two items are world by their country of origin and because they are given world-specific thematic labels. For example, The Patience Stone has the following labels: 'something exotic', 'shamanism', 'feminism', 'Middle East

1 Subtitling is still mostly in English, which shows that this project of creating world cinema worldly is still in the making. 
conflict', and 'human rights'. It is also labelled as festival-awarded, which perhaps increases its aesthetic reliability. Osama comes with other telling labels, however different. They include 'understanding the past', 'social cinema', and 'genocide.' 'Human rights' is the only thematic label that the two films shareand which they also share with the only Senegalese film on the platform, Moolaadé (Ousmane Sembène, 2004) which also bears labels indicating representation of armed conflict and social commentary.

This system of labelling reveals the Euroamerican or Western gaze that constructs world cinema. The labels are indicative of a certain demand that the West expects from the non-global product. As such, the short conclusion of this short study is that world is a shifting category that responds to a centre-margin dialectic and to a commercial demand. I do not claim that this is the definition of world. I only draw attention to the fact that our understanding of world is to a high degree the effect of markets, their location, and the devices enabling and serving the functioning of these markets. My other concluding remark is that approaching the construction of world from a marketing perspective, undermines more essentialist definitions of world as perhaps proposed on sites such as FilmDoo. A market approach envisions world as that which is purchased as world by means of an active purchasing operation on behalf of the client.

This active aspect needs to be highlighted. The advantages of focusing on it are that world is harder to be turned into a genre. Genre, 'science fiction' or 'comedy', is a label proposed and sometimes imposed by makers-vendors and then reinforced by operators in the value chain. Genre creates a certain framework of reception that is more of a closure than a combination of labels that constitute world. This more closed format-reminiscent of genre-is more visible on FilmDoo, which imposes national cinema as a master-context. A combination of labels, like the ones used on Filmin, is perhaps more openended and more indicative of user behaviour. It can become even empowering if these labels can be changed, broadened and combined in multiple ways. They could generate the necessary difference that world conserves, as well as a certain diversity that cannot be contained in only one label reminiscent of genre. 